\title{
Beekeepers' knowledges and participation in pollinator conservation policy
}

Maderson, Siobhan; Wynne-Jones, Sophie

\section{Journal of Rural Studies}

DOI:

10.1016/j.jrurstud.2016.02.015

Published: 25/03/2016

Peer reviewed version

Cyswllt i'r cyhoeddiad / Link to publication

Dyfyniad o'r fersiwn a gyhoeddwyd / Citation for published version (APA):

Maderson, S., \& Wynne-Jones, S. (2016). Beekeepers' knowledges and participation in pollinator conservation policy. Journal of Rural Studies, 45(June 2016), 88-98.

https://doi.org/10.1016/j.jrurstud.2016.02.015

\footnotetext{
Hawliau Cyffredinol / General rights

Copyright and moral rights for the publications made accessible in the public portal are retained by the authors and/or other copyright owners and it is a condition of accessing publications that users recognise and abide by the legal requirements associated with these rights.

- Users may download and print one copy of any publication from the public portal for the purpose of private study or research.

- You may not further distribute the material or use it for any profit-making activity or commercial gain

- You may freely distribute the URL identifying the publication in the public portal ?
}

Take down policy

If you believe that this document breaches copyright please contact us providing details, and we will remove access to the work immediately and investigate your claim. 


\title{
Beekeepers' Knowledges and Participation in Pollinator Conservation Policy
}

\section{Siobhan Maderson sim30@aber.ac.uk DGES Aberystwyth University Dr. Sophie Wynne-Jones s.wynne-jones@bangor.ac.uk SENRGy Bangor Univeristy}

\section{Published in Journal of Rural Studies http://dx.doi.org/10.1016/j.jrurstud.2016.02.015}

\begin{abstract}
This paper considers the potential for beekeepers' knowledges to be incorporated into participatory policy processes addressing current challenges to pollinator health. Pollinator decline is a serious issue for future food security and wider environmental resilience, with important implications for rural land use governance. The precipitous decline in global pollinator populations over recent years has resulted in a range of government
\end{abstract} initiatives to tackle the causes identified. In the UK this includes a National Pollinator Strategy in England and Pollinator Action Plan in Wales. These plans are notable for their introduction of a more participatory approach, incorporating 'lay-knowledge' and citizen science from beekeeping practitioners alongside scientific data. This paper presents evidence from interviews and participant observation with key stakeholders within the beekeeping community in the UK, alongside archival material from the Bee Farmers' Association, to assess the knowledge controversies arising from this strategy. Specifically, the paper considers the distinction of beekeepers' knowledges from typically acknowledged expert sources, whilst also reflecting upon aspects of plurality and tension within the beekeeping community. The paper concludes by outlining some areas of contestation between beekeepers and the wider policy and scientific community, which could impact on the future success of more participatory forums. This includes, firstly, evidence of hierarchies and exclusions in 
the forms of knowledge considered, when insights from professional scientists are privileged above those from beekeepers and when some beekeepers knowledges are given more credit than others. Secondly, we consider limitations resulting from policy makers' evidence requirements for peer-reviewed science, which can further exacerbate the exclusion of beekeepers' insights and lead to scenarios whereby policy only engages with a narrow set of criteria that may not be beneficial when advanced in isolation from the broader system changes. Finally, aspects of policy clash are outlined between pollinator conservation and wider agricultural strategies that seek to maintain a productivist agenda.

\section{Key Words:}

Diverse expertise; knowledge controversies; participatory governance; citizen science; beekeeping; pollinator health.

\section{Highlights:}

- Evaluation of beekeepers' knowledges as forms of diverse expertise.

- Assessment of the role of beekeepers in participatory policy forums.

- Assessment of knowledge controversies arising. 


\section{Introduction}

This paper considers the potential for beekeepers' knowledges to be incorporated into participatory policy processes addressing current challenges to pollinator health. Pollinator decline is now recognised as an urgent global issue, given the critical role of pollinators in ensuring food security and wider environmental and social well-being (UNEP 2010; DEFRA 2014). Whilst a number of species act as pollinators, honey bees have been the subject of sustained scientific attention as a key indicator species for wider pollinator and ecosystem health (Kevan, 1999). In the UK Apis mellifera, the western honey bee, provides pollination for approximately 34\% of commercial crops (Breeze et al. 2012) and plays a fundamental supporting role for biodiversity. Financially, the value of pollination as a contribution to the UK crop market was $£ 430$ million in 2007 (UKNEA 2010). In Wales the wholesale value of honey was estimated at over $£ 2$ million in 2011 (WG 2013). Yet honey bees and other pollinators face serious challenges here, as they do internationally (Potts et al. 2010a).

Many of the challenges to pollinator well-being are directly linked to the prevailing food system, which is geared towards the production of inexpensive food through deleterious practices (Ericksen et al. 2009). Problems include intensive pesticide usage, which is directly harmful to bees (LWEC 2015), and a decrease in the quality and quantity of forage for bees to feed on, due to widespread habitat loss and the cultivation of monocultures (Naug 2009). The prevalence of diseases such as varroasis ${ }^{1}$ is also a major threat (Dietemann et al. 2014). Moreover, some researchers are concerned that bees are becoming less resilient to disease due to the importation of poorly adapted genetic strains and more interventionist beekeeping practices (Le Conte et al. 2007; Locke \& Fries 2011). Finally, changing climates and more

\footnotetext{
${ }^{1}$ Varroasis is caused by parasitic varroa mites, and is capable of killing whole bee colonies if left untreated. See http://www.nationalbeeunit.com/index.cfm?pageid=93 [last accessed 30/12/15].
} 
extremes in weather add a further stress factor, particularly through the impact on forage availability and disruption to the climatic niches different species require (DEFRA 2014; Potts et al. 2010a). However, causes of decline are acknowledged to be complex and in some instances hotly contested (Philips 2014; WG 2013).

In the UK, government is attempting to respond to these issues through policy programmes such as the Wales Pollinator Action Plan (WG 2013) and subsequent UK National Pollinator Strategy (DEFRA 2014). A hallmark of these programmes, and our reason for focusing upon the UK case, is their aspiration to advance a more participatory forum for policy development and deployment, which is currently unprecedented in international pollinator policy fora. This involves including a wider range of stakeholders in the policy process, with differing forms and degrees of expertise, including those who do not have formal scientific or policy training. It also assumes a greater degree of transparency in decision-making processes and greater collective responsibility in the deployment of governance (Reed 2008). However there is no standardised approach and a range of participatory measures have been witnessed across the fields of rural and environmental governance in recent years (see e.g. Blackstock et al. 2014, Cook et al. 2013).

Explaining their aspirations for a more participatory approach, the Welsh Government outline that:

"There is currently no central focus point in Wales for work and information on pollinators, although many of our stakeholders work together for common aims. Bringing together all of those with an interest in pollinators and their management and conservation is an important area for action for this plan." (WG 2013 p13) 
The UK Department for Environment Food and Rural Affairs (DEFRA) echo these sentiments, stating their priority "to improve knowledge sharing on pollinators' needs between scientists, conservation practitioners and NGOs” (DEFRA 2014 p23); making explicit reference to the need for citizen science to ensure sustainable monitoring of pollinator health into the future.

Whilst a diverse range of stakeholders are involved in both these policy programmes, beekeeping practitioners are acknowledged as primary stakeholders (DEFRA 2014; WG 2013), and their expertise is being sought to supplement, and develop, conventional scientific data. Given beekeepers' regular contact with bees, they are well placed to collect and relay a range of data, participating as 'citizen scientists'. The importance of their role is highlighted by Potts et al. (2010b), who state that beekeepers have a distinct knowledge system, acquired through their practice, which is formative in their ability to interpret and ultimately support pollinator health (see also Philips 2014).

However, the incorporation of such diverse expertise is not without difficulties: conflicts are evident regarding what and whose knowledge is most valid. This resonates with similar controversies arising in other participatory forums tackling environmental management and rural land use (Eden et al. 2006; Goldman et al. 2010; Philipson et al. 2012; Proctor et. al 2013; Ruiz-Mallen and Corbera 2013; Whatmore 2009). Tensions are particularly notable when the blame for pollinator decline is being laid at the door of agri-business. For example, agrochemical firms such as Syngenta have been very active in calling for the recently instated EU neonicotinoid moratorium ${ }^{2}$ to be repealed (Bates 2015). UK farming unions have equally been reluctant to accept many pesticide restrictions (Farming Online 2015). This is echoed by

\footnotetext{
${ }^{2}$ Neonicotinoids are a class of insecticides which affects the central nervous system of insects. For information on the EU moratorium see http://www.eea.europa.eu/highlights/neonicotinoid-pesticides-are-a-huge [last accessed 24/7/2015].
} 
debates in the US on the causes of Colony Collapse Disorder $(\mathrm{CCD})^{3}$, which have flared-up between beekeepers and Environment Protection Agency regulators (Suryanarayan \& Kleinman 2013).

Notably, many of these arguments have hinged around whether particular forms of knowledge are seen to be accurate and dependable (ibid; Wynne 2002). Beekeepers often find that their perspectives are not granted the same weight as others and fall outside the parameters of conclusive scientific evidence. But it is equally important to note that there are a diverse range of perspectives amongst beekeepers themselves (Moore and Kosut 2013). The construction and contestation of beekeepers' knowledges is, therefore, a key area for study in the advance of effective pollinator policies.

This issue forms the focus of this paper, which reports on research with the beekeeping community in Wales and England, including interviews and participant observation with key stakeholders, and analysis of the Bee Farmers' Association archives. It is not the aim of this paper to evaluate the extent to which effective participation is being achieved through the WPAP or DEFRA's Pollinator Strategy, as both are only in their early stages ${ }^{4}$, rather our aim is to explore the specificity of beekeepers' knowledges and the challenges they perceive in securing a more supportive policy environment for pollinator health. Further research is planned to gain a wider reaching perspective on the successes and failures of the respective policy forums as they progress.

The paper is structured as follows: in section 2 we position the paper in relation to relevant literature on bees and social science, knowledge controversies, diverse expertise and

\footnotetext{
${ }^{3}$ For further information on CCD see http://www.ars.usda.gov/news/docs.htm?docid=15572 [last accessed 24/7/2015]

${ }^{4}$ Particularly the DEFRA strategy which was not published until after the research for this paper was completed.
} 
participatory governance. In section 3 we outline the research methods. In section 4 we consider the distinction of beekeepers' knowledges from scientific studies, whilst also acknowledging areas of plurality and tension within the beekeeping community. Section 5 then reflects on areas of contestation between beekeepers and the wider policy and scientific community, assessing the potential impacts of such knowledge controversies. Section 6 provides some concluding statements regarding the issues to be addressed to enable future success in more participatory policy forums.

\section{Literature Review}

\subsection{Bees and Social Science}

Whilst there have been continuing advances in the natural science dimensions of pollinator health, there is a pressing need to connect this with more critical social enquiry in order to gain a better understanding of beekeeping practices 'on the ground', not only in the lab. As Philips (2014) outlines, social science coverage of bees and beekeeping has been limited. Her work with commercial beekeepers in Australia explores the more-than-human interface involved. Through a blending of social practice theory and more-than-human studies ${ }^{5}$ she draws attention to the 'shared labour' of beekeeping, acknowledging the agency of the bees and beekeepers. Richard Nimmo (2015) similarly draws inspiration from more-than-human studies to theorise the treatment of bees and swarms within the contemporary agri-food complex, reflecting on the ethics of care and politics of order advanced. The need to attend to the interrelations between bees and beekeepers, and the resulting modes of production is, therefore, evident as a key tenet of this emerging field of social enquiry.

\footnotetext{
${ }^{5}$ More-than-human studies combines insights from Actor Network and Assemblage theories to consider the agency of non-human actors (animals) and actants (things); see Bennett (2010) for a seminal introduction.
} 
Bees are different from other animals previously considered by rural studies (e.g. Buller and Morris 2003; Yarwood and Evans 2000). Whilst they are 'farmed' for their produce they remain wild in many ways, ensuring a very particular dynamic to the relationship between bees and their 'keepers'. This interaction is, however, acknowledged to be vital in gaining insights into bee health (Potts et al. 2010b); hence the need for further study into the formation of beekeeping knowledges and practice. As Philips' (2014) study shows, ethnographic enquiry following day-to-day practices can offer important insights into beekeepers' decisions and the factors influencing the resulting modes of husbandry pursued. It also enables attention to the influence of emotional, visceral and easily overlooked routine components of interspecies contact (see also Moore and Kosut 2013, 2014). It is for these reasons we incorporate this approach into our methodology as detailed in section 3 .

\subsection{Knowledge Controversies}

Despite the valorisation of some beekeepers' insights, and policy rhetoric advocating wider participation in pollinator science, it is clear that challenges exist. As Suryanarayanan and Kleinman (2013) outline, beekeepers' understandings are not always easily translated into wider decision making forums. Grounded in science and technology studies, their analysis demonstrates that different forms of knowledge are granted particular status, and are consequently deemed to be more or less valid. Their insights resonate with wider studies of environmental controversy where knowledge of nature is seen to be "complex, multiple and highly political" (Goldman and Turner 2011, p1). Their work highlights the distinctions held between science and 'lay knowledges' and the difficulties this can create for incorporating

diverse expertise into policy processes. They frame 'expertise' as a social process rather than a given category, drawing attention to what is counted as relevant knowledge, how that came 
to be, and who possesses such knowledge to inform policy debates; key points for our own analysis.

The politics of knowledge has gained increasing attention in recent years, as aspirations to incorporate diverse expertise has burgeoned across a range of rural land-use and environmental issues (Blackstock et al 2014; Fazey et al. 2013; Lane et al. 2011; Reed 2008; Philipson et al. 2012). Similarly, there has been an increasing emphasis upon citizen science to support data collection and maximise research impact through greater societal involvement (Cooper et al 2007; Haklay 2013). This has included a range of publics, including indigenous communities in geographically remote situations, where sustained interaction and immersion within an environment offers a useful compliment to 'expert' data collection which can be limited in both timeframe and breadth of observation (Davidson-Hunt 2006; Royer et al. 2013). These indigenous insights are often referred to as forms of 'traditional environmental knowledge' (TEK) (ibid). Whilst such framings are not fully compatible with Western beekeepers, there are some useful resonances which we will go on to outline in the analysis.

\subsection{Diverse Expertise \& Participatory Governance}

The inclusion of increasingly diverse expertise can be framed as a more participatory approach to governance (Wynne-Jones et al. 2015). This has occurred in the context of increasing environmental uncertainties (Whatmore 2009); the recognition of complexity in environmental systems' management (Fish et al. 2010; Funtowicz and Ravetz, 1993); and greater public questioning of expert-knowledges (Conrad et al. 2011; Forsythe 2011; Zimmerer 2011; Vandergeest and Peluso 2011). Connecting with this later argument, Cook et al. (2013, p756; drawing on Jasanoff 2003) argue that greater citizen participation can lead to a more democratic model of science and society, "as it is neither scientifically nor politically 
sensible to allow power over decision-making to concentrate exclusively around particular knowledges or knowledge producers". Moreover, it is increasingly acknowledged that the crises of food security and environmental resilience cannot be addressed without recourse to the insights of 'traditional environment knowledges' (Barthel et al. 2013; Berkes et al 2000; Ruiz-Mallen and Corbera 2013; Pretty 2003).

Nonetheless, despite high level advocacy, the utilisation of 'lay' knowledges has been the subject of considerable debate (Whatmore 2009; Woodyer and Geoghehan 2012). The various factors involved provide a starting point for our own analysis. Firstly, the attainment of data standards is noted as a key issue. At a basic level, scientists express concern as to whether untrained publics can be trusted to collect robust data (Riesch and Potter 2014). More substantively, the need to conform to processes of categorisation and ordering required for scientific knowledge production and circulation has challenged lay and indigenous practitioners whose knowledge making practices may not fit the required mould (see e.g. Ellis and Waterton 2005; Goldman et al. 2011; Lorimer 2008). Exemplifying this issue in relation to beekeepers' knowledges, Suryanarayanan and Kleinman (2013, p222) outline that beekeepers use 'informal' measures to assess their hives and bee health: "[these] do not easily lend themselves to standardization or quantification and are considered anecdotal from the standpoint of academic scientists". But they are important to beekeepers because they "package complex information with multidimensional aspects into knowledge useful and meaningful to beekeepers". Hence we can see that the type of information beekeepers would use and find meaningful is not necessarily in line with the requirements of other actors.

A related concern is that some ways of knowing and engaging with the world imposed by external actors (scientists or government) can make it difficult for lay and indigenous 
knowledges to be utilised to their fullest benefits. For example, Nadasdy (2003) addresses the challenges encountered by First Nation peoples when working with the Canadian central federal government. Efforts to devise land management strategy in this case have led to the former having to speak, work, and think in the philosophical and cultural language of the latter. This ultimately serves to undermine the unique benefits of the First Nation's TEK perspective, as it is fundamentally altered by being forced through the analytical framework of government policy and practice.

Further difficulties are evident around the ownership and control of knowledge. If citizens or indigenous communities collect and supply data, what happens next? All too often the capacity to define questions and draw conclusions remains with certified experts or government officials (Wynne, 2003), leaving participants disenfranchised (Ellis and Waterton 2004). A final point to note is the importance of other framings which can inform how data and scientific knowledge is acted upon; for example, the extent to which different cultural views of nature can affect management choices. This is demonstrated by Enticott's (2008) work on farmers' responses to disease prevention, Eden and Bear (2011) on fishermens' understandings of riparian management, and Cornwall and Campbell (2012) on conservation volunteers' reactions to sea turtle management. In all of these examples, the particular cultural influences and priorities of the stakeholders listed influences their responses, resulting in decision-making that is based on much more than whether or not they understand the science. This further reinforces the need to address social parameters of knowledge formation and application, demonstrated through this section. 


\subsection{Applications}

Applying these insights to beekeepers' knowledges suggests a complex picture, given the plurality of beekeepers' knowledge basis and the diverse influences on their practice. Approaches to beekeeping range from 'extensive' to 'intensive' approaches ${ }^{6}$ (Lowore and Bradbear, 2011). Suryanarayanan and Kleinman (2013) describe beekeepers as possessing 'contributory expertise' (following Collins and Evans (2007). That is, expertise gained through long term and intimate observation, as opposed to formal scientific qualification; akin in many ways to indigenous TEK systems. But many beekeepers are also literate, or even trained, in scientific terminology, so the division is not clear cut. Exploring the distinctions, and overlaps, between scientific ways of knowing and other, more experiential and intuitive forms of beekeepers' knowledge is therefore a key component of our analysis; as is tracing the factors formative in the construction of these knowledges.

Reflecting on the emerging controversies, it is important to note that beekeepers in our case are being actively enrolled into participatory policy forums, rather than starting from a position of opposition as they have in Suryanarayanan and Kleinman's (2013) US study. The distinctive approach to policy making considered here therefore offers new insights. In addition, the UK beekeeping sector differs from the intensive and heavily productionorientated priorities of the US and Australian industries covered by previous studies, with more smaller-scale and non-commercial practitioners here ${ }^{7}$ ensuring the presence of diverse rationales.

\footnotetext{
${ }^{6}$ Extensive beekeeping involves an approach to bee health and productivity which emphasises the fundamental linkages between bees and their wider ecosystem. Intensive beekeeping is generally associated with a more interventionist approach.

7 This is supported by the fact that membership of the less commercially orientated Bee Keepers Association is substantially higher (24,000 members) than the Bee Farmers Association (300 members) - personal communication with Chairman of BFA.
} 


\section{Methods}

Research for this paper involved interviews, participant observation and archival analysis in the UK. As outlined above, the aim of this data collection was to explore the distinctions and influences upon beekeepers' knowledges and to assess emerging controversies which could affect the success of the participatory policy forums introduced in Section 1. Given this focus, a mixed-method qualitative approach was applied to provide both depth of insight, into current processes of knowledge production and circulation, and a broader geographic and historical perspective on the exchanges in question.

In-depth interviews and observations were carried out with sixteen beekeepers who were chosen as key stakeholders, and/or representatives of particular sub-categories of beekeeper based on a range of criteria (details of interviewees are provided in Appendix A). Preliminary research highlighted certain factors influencing beekeepers' knowledge and practices, including but not limited to, length of time and motivations for beekeeping. Consequently, interviewees with varying levels of experience were chosen, ranging from three to forty years. They also included commercial bee farmers, long term beekeepers who were active in teaching and training of new beekeepers, and amateur hobbyists who had very recently taken up this pastime. Of this latter group, further subdivisions were represented by including respondents who had come to the activity driven by a distinctly environmental motivation, and those whose interest was more general. Some respondents expressed an affinity for a more 'extensive' approach, while others followed a more 'intensive' approach including the use of chemicals. 
Respondents were also chosen to reflect differing degrees of engagement with the policy forums in question. For example, whilst some individuals were actively involved in the policy processes, and some members of organisations officially recognised as 'stakeholders', others expressed a belief that their approach to beekeeping and bee health is not fully acknowledged in policy fora. Given that the Welsh policy process is significantly more advanced than its English counterpart, as outlined in Section 1, interviewees were predominantly sought in Wales ${ }^{8}$. However, some respondents have connections to both the Welsh Government and DEFRA processes (as shown in Appendix A). In addition, advice was sought from a DEFRA researcher (Interviewee 15) who has conducted research with beekeepers across the UK to cross-reference our analysis. Moreover, the use of UK-wide archival sources enabled us to draw broader conclusions of relevance to both countries.

Interviews were conducted either in respondents' homes or places or work. They explored beekeepers' own knowledges and practices and the various influences on these, including the role of their peers, supporting organisations and formal training. They also focused on beekeepers' understandings of the threats to pollinator health, including the impact of agricultural and wider policy initiatives on beekeeping. Where relevant, interviews focused on experiences of contributing to the policy processes in question and respondents' views of the outcomes thus far. Participant observation was used to support and extend the interview process by accompanying interviewees as they inspected their hives, enabling questions to be raised on practices being observed. Talks and lectures at the local beekeepers association and annual conferences were also attended to gain insight into the concerns and perspectives of the wider beekeeping community; corroborating and enhancing the insights from the other sources outlined (these are listed in Appendix B, with a summary of the key topics covered).

\footnotetext{
${ }^{8}$ The DEFRA Pollinator Strategy was not released until after the research for this paper was completed, but was seen by many respondents as learning directly from the successes of the WPAP.
} 
This data was supplemented with archival analysis, which focused on records from the Bee Farmers Association (BFA), the trade organisation for professional UK bee farmers. This included bulletins sharing insights, experiences and concerns of members, going back to the association's formation in 1953, as well as minutes from conference meetings covering the same period ${ }^{9}$. These archives provide a unique insight into the knowledge and concerns of bee farmers since the mid- $20^{\text {th }}$ century, giving coverage of the dramatic changes experienced over that time. This includes the impact of agro-chemicals and other changes in agricultural practice on bee health; environmental changes, and developments in beekeeping practice. The historical relationship between beekeepers and the wider policy arena is also documented in the archives, providing a long-term insight into how some beekeepers' experiential knowledge has been used and regarded by government and scientific researchers. The early editions of BFA bulletins were primarily written by men who had learnt beekeeping in the very early $20^{\text {th }}$ century, thus providing an additional, deeper historical lens to the data.

The combination of archives, interviews and participant observation provided rich data on the concerns, values and challenges faced by beekeepers, both professional and amateur, over the past sixty years. As noted at the outset, the data presented is not intended to represent a full evaluation of policy processes, and further research is planned to address this. It is also acknowledged that further data from beekeepers in England will strengthen the analysis offered here. Nonetheless, it is argued that the combination of sources addressed here reflects a robust analytical approach, providing a clear set of preliminary themes which can be explored further in subsequent work.

\footnotetext{
${ }^{9}$ These archives are not formally catalogued and referencing of this material therefore refers to specific published material, such as bulletins whenever possible.
} 


\section{Beekeepers' Knowledges}

The following two sections (4 and 5) present our data analysis. In this section we consider the difference between beekeepers' knowledges and the typically acknowledged expertise of scientific studies, whilst also acknowledging areas of plurality and tension within the beekeeping community. This is then used to inform our assessment of emerging conflicts and barriers to the success of more participatory policy making in section 5 .

\subsection{Citizen Scientists}

Beekeepers are widely acknowledged as being on the front-line of understanding pollinator health because their day-to-day practice necessitates continual, regular engagement with bees. Record-keeping on bee health, wider environmental conditions and quantities of honey produced, is part of many beekeepers' standard practice. This data lends itself to utilisation as citizen science, given the synergies with conventional scientific observations; in these terms such observations are akin to a longitudinal and multi-variant study. Demonstrating these synergies two interviewees, who were both long term beekeepers and research ecologists, outlined that that they had considered publishing their personal records and observations in scientific journals.

More widely, BFA archives show a consistent trend of their members being ahead of the curve in recognising patterns in pollinator health, and their observations have played a key role in evidencing policy changes throughout the Association's existence. For example, beekeepers regularly expressed concern over declining hedgerows, the removal of fruit orchards, and the reduction in crop diversity. These issues are now scientifically recognised as a threat to pollinator wellbeing. The archives also document a long history of BFA 
members providing samples and data for researchers at Rothamsted ${ }^{10}$. In particular, BFA members were encouraged by scientific researchers to submit samples of bees they believed to have died as a result of pesticide spray incidents. These samples provided scientific proof of the hazardous impact of many agrochemicals used in the mid- $20^{\text {th }}$ century (BFA Bulletins 54: March 1960; 108: October 1967; 180: July 1978). This material was central to many advances in scientific understanding of bee health and many agricultural chemicals are now banned in recognition of this evidence.

BFA archives first document the threat of varroasis to bees and beekeepers long before it received wider scientific attention. (BFA Bulletin 185, February 1979). During the mid-1980s the efficacy of varroacides was widely debated amongst BFA members, long before the mite hit media headlines. And in 1984, the BFA recommended to the UK Ministry of Agricultural Fisheries and Food that bee imports be banned as part of a strategy to limit varroa's advance in the UK (BFA Spring Conference minutes, 1984). Here the lines between conventional and citizen science are evidently blurred.

\subsection{Other Ways of Knowing}

However, whilst there is clear overlap with scientific practice, the intuitive element utilised by beekeepers when assimilating their evidence often takes decision-making into a realm beyond science. Science is reductive by nature, requiring fixed variables and controls, but the world beyond the lab is not like that. All interviewees emphasised the importance of the actualities of the highly complex world in which their pollinators operate. As Suryanarayanan and Kleinman (2013, p222) outline:

${ }^{10}$ A long-standing agricultural research station noted for its work on bee health. 
"Beekeeper knowledge is constructed via practices that take an informal epistemic form, which makes them conducive to the highly dynamic, local, variable, and complex aspects of their operations..."

Their resulting knowledges are consequently more fluid and contingent, and the acknowledgement of their differing basis of knowledge construction makes many approach formal scientific findings on pollinators with a cautious reserve. Respondents - both longterm and comparatively new beekeepers - outlined that they regard many scientific studies as too narrow in their focus and irrelevant to their experience, which requires a more holistic engagement with the bees and the wider environment. Many of the more experienced beekeepers referred to the role of instinct and/or serendipity in their success with their bees:

"[As a beekeeper] you want to be able to interpret [environmental conditions] correctly... And sometimes you can get it right just by chance. Sometimes it just goes completely haywire. (Interviewee 4)

Attitudes towards science, and the development of their practice more broadly, was clearly influenced by the different ways beekeepers learnt their practice, and what sorts of information sources they used and trusted. All respondents stressed the importance of direct experiential learning of beekeeping, coupled with an eagerness to learn from 'old-timers' beekeepers with more than thirty years of experience. While formal study of beekeeping and a high level of engagement with scientific literature was a part of many beekeepers' education, the irreplaceable nature of direct experience and attention to local conditions was emphasised as being fundamental to successful beekeeping. Respondents and archives reflect a consistent theme of beekeepers assessing scientific advice alongside first-hand experience. All respondents (regardless of age, gender or background) stated the paramount importance 
of experience. In particular, more experienced respondents - both commercial and hobby beekeepers - were emphatic about the constant learning process involved with their beekeeping. This learning is primarily rooted in observation and analysis of one's own bees. One interviewee, who has kept bees over thirty years, stated:

“We took a conscious decision to put books and advice 'over there'... it's a matter of don't learn the practices of a beekeeper. Learn what the honeybee response is. Read your bees!!!” (Interviewee 12)

Nonetheless, interviews and archives suggest that many practitioners (including the person quoted above) do commonly use a variety of both peer-reviewed science and practical experience to guide their relationship with their bees.

Both interviews and archives suggest that beekeeping leads to changes in perception - of bees and the wider environment. Experienced beekeepers all stressed the importance of developing multi-sensory sensitivity to one's bees as a key aspect of successful practice. Learning to distinguish the different sounds emitted by bees, the smell of the hive, and the behaviour of bees entering and leaving a hive are all encouraged as ways of monitoring hive health. The richness of beekeepers' observations is, therefore, not simply a result of regular contact but a shift in perspective which develops over years of experience, as described below:

"When I drive around the countryside now, I find myself looking at it in terms of bee habitat...I just see the whole countryside now as bee forage. It's completely changed the way I think about the seasons, too. Now, summer ends at the end of July, when most of the honey flow is over." (Interviewee 7) 
Beekeepers also describe feelings of connection \& stewardship:

"I find the process of beekeeping, the seasonality, the insects themselves, fascinating... that's an amazing thing to have, as part of your interest, and your connection with the seasons, with the natural landscape, your role in that, and your position - well I think it's a position of humility - as custodian of a semi-wild animal, really." (Interviewee 5)

With regards to issues of disease, beekeepers' emotional engagement can complicate decision-making. This is different from other perspectives of the owner and pet, or farmer and livestock, as the beekeeper acts more as a steward for a wild creature. Yet there is clear connection, sensitivity and sometimes discomfort; for instance when respondents balance the impact of varroacides against concerns for short and long-term bee health. Emotional influence is completely alternate to the ideals of scientific practice, but it has led to important observations when beekeepers have chosen not to treat their bees. The potential to breed-out weaker bees and promoting stronger genetic stock has led some respondents to believe that applying chemicals can lead to the lowering of colonies' resilience. This perspective was more common amongst new beekeepers who have recently taken up the activity, and selfidentified as being motivated to keep bees due to environmental concerns regarding pollinator decline. This attitude seemed slightly more common amongst female respondents, although further research would be necessary to assert a definitive gender link. There has been limited scientific research on potential benefits of discontinuing chemical treatment for varroa. However, some studies do back up this 'on the ground' concern (Le Comte et al. 2007; Locke \& Fries 2011). Whilst it is far from a clear cut picture, interesting observations result from beekeepers' intimate and caring relations with their bees, which often precede, and even supersede, conventional scientific analyses. 


\subsection{Tensions between Beekeepers}

This issue of how to deal with varroa is a particularly emotive one within the beekeeping community, with radically differing perspectives evident. The National Bee Unit (NBU) advises all beekeepers to regularly monitor their bees for varroa infestation, and treat hives with varroacides regularly. This advice is followed by most beekeepers, but as the above discussion indicates, a small but significant number of beekeepers question this advice. Many of those who disagree with this stance on varroa also question the wider paradigm of modern agriculture with which the NBU is associated. The following two quotes from interviewees each one a highly respected, experienced voice within one of two distinct sub-communities of beekeepers - illustrate the diametrically opposed views on this highly controversial issue:

"so if you're not going to treat for varroa, and you are going to just let your hive do what it wants, then your (bees) are going to cause a problem for everybody else." (Interviewee 12)

"on the varroa issue, I think it's best to expose bees to full force of natural selection. When I started, I was a treater... Now I don't even treat them. So all my bees are exposed to the full force of natural selection. My mentor said 'you don't want to kill all the mites, because the bees are going to have to learn to adjust to them." (Interviewee 13)

Another notable area of divergence in opinion emerged around the perspectives arising from, and towards, newer beekeepers. Many interviewees commented upon the recent surge of interest in beekeeping and this is further evidenced by the increased membership of local 
beekeeping associations (with some experiencing a quadrupling of members over the past five years). Many new beekeepers interviewed were driven by media attention to the plight of the bees and a desire to 'do one's bit'. This new generation of beekeepers has produced a shift in the demographics of practitioners. While archival analysis and interviews both point to a historical tendency for beekeeping to be a predominantly male pastime, generally driven by a desire to extract honey, those who are new to the practice speak of their beekeeping in a more environmental context. This quote epitomises the view of many of the new generation of 'hobby' beekeepers:

"I'm not in it for the honey - Jesus, no! ... If I get $10 \mathrm{lbs}$, that's enough to give to the in-laws and that's what it's about. Money - (beekeeping is) a hole in the pocket, isn't it? I've always known that. If you want to make money, you get yourself a field and put loads of hives in it. And there are risks there. I'm not interested in that. I'm interested in bee wellness, and people coming to have a look. That's nice." (Interviewee 6).

Many of these new beekeepers expressed a desire to use a more extensive approach, which avoids applying chemical treatments, and places emphasis on the importance of wider ecosystem health and wellbeing. Whilst they perceived this as a 'new' approach, it has much in common with early $20^{\text {th }}$ century European practices and those of beekeepers in the Global South. Interestingly, this approach has parallels to TEK systems, where human relationships with other species are governed by a sense of stewardship and conservation.

There can be frequent tensions between practitioners who use different methods of beekeeping. Some interviewees who questioned features common to modern beekeeping treating for varroa, importing queens, controlling swarming - reported animosity from other 
beekeepers who engaged in such standard practices. While analysing the impact various practices have on bee health is beyond the remit of this paper, it is important to address these tensions within the beekeeping community. We also note that most 'citizen science' input from beekeepers tends to be from those who ascribe to comparatively intensive modern practices. For some on the opposite end if the spectrum, the very nature of gathering data as per modern beekeeping methods is considered inappropriate:

"But if you're a 'natural' beekeeper you're not going to be doing intrusive inspections. So you're not going to find the same data.., because you are leaving the bees to work it out themselves." (Interviewee 3).

Overall, as the political and environmental perspective of beekeepers has widened and diversified, so has the view of what is best for bees, and how the environment, and bees, should be managed. The diversity and distinctions of these knowledges impacts on how effectively they are incorporated, and subsequently deployed, in policy processes to manage bee health - as we go onto discuss below.

\section{Knowledge Controversies}

In this section, we draw on the divisions and tensions outlined in section 4 to inform an analysis of emerging areas of engagement and contestation, which may impact the future success of participatory policy forums.

\subsection{Hierarchies and Exclusions}

Despite many instances when beekeepers' observations have been used to inform policy and science, as outlined in section 4.1, the BFA archives also show episodes of controversy. In many cases there was a notable lag-time between declarations of concern from beekeepers 
and follow-up research (this is shown in the archival records discussed in section 4.1). In addition, beekeepers found their knowledge was dismissed as 'anecdotal' until formally recognised and/or replicated in scientific studies. The archives also document an ongoing sense of frustration amongst members who feel their occupation is not understood or appreciated by government. For example, the following extract from a beekeeper who presented evidence to Parliamentary Sub-Committees, illustrates concern that their practical observations and knowledge is not granted equal status:

"I have been following the proceedings of the Environmental Audit Committee relating to their investigation of Insects and Insecticides. It is apparent that most of the evidence submitted is based on scientific research, with varied interpretations. Very little evidence has been based on "hands on" field experience." (Orchid Apiaries 2013).

This privileging of scientific data echoes the situation that Suryanarayanan and Kleinman (2013) report on in the US. And whilst it is evident that beekeepers' observations are deemed dependable in some instances, or at least indicative of credible concerns, there is still a clear hierarchy of knowledge practices and typologies. This presents challenges to the function of more participatory policy processes if beekeepers are disinclined to engage because they feel un(der)valued, as 'second rate' sources; or worse, if they lack confidence in the process of decision making. Despite the promise of current aspirations for more participatory forums, the longstanding tensions evident in the archives suggest a sustained experience of disenfranchisement for beekeepers, which was similarly reported by several interviewees. This conflict between stakeholders centres on the differing forms of knowledges they rely upon and ultimately trust, as is the case with an increasing number of environmental controversies (Eden et al. 2006; Philipson et al. 2012). Equally, it is about the power differentials associated with the utilisation and production of particular forms of knowledge, 
and the levels of access and influence this can create (Ellis and Waterton 2005; Whatmore 2009).

A further dimension to this politics of knowledge co-production, that interviewees noted, was the marked differences between which beekeepers were listened to. For instance, participation in the Wales Pollinator Action Plan (WPAP) clearly privileged those affiliated with official groupings (i.e. the BFA and Bee Keepers Association). By contrast, as noted in section 4.3 , many beekeepers who came to the practice primarily motivated by environmental concerns found their views and practices were often criticised by both the scientific community and other beekeepers. This has meant that such beekeepers do not become members of official groupings. While their knowledge of bee and wider ecosystem health may be of relevance, it is difficult to access due to their lack of affiliation with governmentacknowledged statutory organisations. Moreover, the contestations between beekeepers that we have outlined can make it difficult for policy makers to know who to listen to, and reduces the perceived credibility of such practitioners overall (Interviewee 15). Here we see that knowledge controversies can exist both between and within scientific and lay knowledges.

\subsection{Evidence Requirements}

Reflecting more specifically on the policy programmes under development, it is notable that the WPAP has received a great deal of praise and support by beekeepers' organisations, conservation ecologists, and environmental organisations ${ }^{11}$. Echoing these sentiments, interviewees thought it was laudable that the WPAP frames pollination as a biodiversity issue, reflecting a more thorough-going ecosystem level analysis. They also supported the

\footnotetext{
${ }^{11}$ See http://www.foe.co.uk/news/welsh_bee_action_plan_launched_40860 [last accessed 27/07/2015].
} 
WPAP's identification of five main threats to pollinators including: land use intensification, habitat loss and fragmentation, disease, agro-chemicals, and climate change (WG 2013, p12). However, it was noted that whilst there is sufficient data to warrant immediate changes to address these threats based on the precautionary principle, the WPAP calls for further scientific research (WG 2013). This highlights governments' need for a peer-reviewed evidence base to support policy making.

Whilst this requirement is intended to produce a more robust and considered approach, it can create tensions as policy-makers' preference for reductive scientific data sometimes means that the complex system dynamics affecting bee health are not fully acknowledged. In some instances, this limitation has led to arbitrary target-setting where policy-makers have been keen to include measurable outputs linked to selective scientific studies. Consequently, interviewees argued that some WPAP objectives do not represent a full understanding of the dynamic and multiple variables involved in pollinator health, and only address a narrow continuum of factors.

A case in point is the issue of declining bee forage, and government's recommendations to address this by planting wild flower corridors on verges and roadsides. This action follows various studies highlighting the benefits of increased habitat corridors (e.g. Breeze et al. 2012). Whilst the benefits of an increase in habitat was not questioned by respondents, they do criticise the governments' choice of location:

“Roadside verges aren't the best places to have pollinators...because they're going to get squashed." (Interviewee 12) 
Others contend that a more systematic response is necessary, highlighting that piecemeal approaches to provide more forage are insufficient on their own: "The forage they do have MUST NOT be poisoned!!! ... Pollution of the environment, and forage, is a big problem." (Interviewee 3). Interviewee 16, an experienced professional botanist and second generation beekeeper who was closely involved with the WPAP, similarly questioned the rationale of this strategy and reported government negation of his counter recommendations; demonstrating the widespread level of tension on this issue.

What respondents were highlighting here was the need for a more thorough-going response to tackle the negative effects of the current agricultural system. But this is a substantive political challenge, and in light of the complex system dynamics involved the science is not fully clear (Philips 2014; Suryanarayanan 2015). It is perhaps, therefore, not surprising that government seems to be prioritising easily attainable targets where the science appears firmer to avoid having to make difficult decisions that are potentially unfavourable with powerful actors. Here the importance of unravelling the social and political context behind data standards is apparent (following Goldman et al. 2011). The policy system's specific criteria for the construction of validity delimits what information can be considered and what cannot. As such, essential factors are not addressed if they cannot be 'proven'. Hence, we arrive at a position where policy only engages with a narrow set of criteria which may not even be beneficial when advanced in isolation from the broader system changes.

Suryanarayanan's recent (2015) comments about the need to broaden the knowledge basis of policy decisions on pesticide usage resonate strongly with this point. He argues that it is important to acknowledge the methodological and epistemological limits of what is traditionally taken as 'evidence' and consider a wider continuum of knowledge types; even if 
this goes against policy makers' desire for 'certainty' and 'control'. This is in order to advance a more precautionary approach which has been shown to be needed in many cases:

"A pollinator policy that ignores the ecological complexity in which honey bee colonies operate, even if scientific knowledge about it is highly uncertain, risks perpetuating a system in which honey bees, beekeepers and other insect pollinator species will continue to struggle.” (ibid, p 150).

However, as Higgins et al. (2014) note, the increasing neoliberalisation of rural governance is set to exacerbate this problem of inflexible (and ultimately inadequate) data requirements. This is due to greater emphasis upon 'governing at a distance' and citizen participation through very particular technologies of rule, which allow little accommodation of the diversity of knowledge systems utilised by rural actors. The associated professionalization of expertise, as a facet of neoliberal governance, similarly intensifies such demands for data standards and specific modes of codification. The influence now exerted by these cultures of expertise is demonstrated by the depth of purchase such ways of knowing have across society more broadly (Laurie and Bondi 2006; Miller and Rose 2008). This suggests that the difficulties documented here are not unique to beekeepers.

\subsection{Policy Clash and Systematic Change}

The final area of tension emerging was the perceived policy clash, indicated in the preceding section, between the proposed WPAP actions and wider agricultural strategy. One example given by a respondent, who is a long-term beekeeper and also employed as an agrienvironment advisor, was advising farmers to cut hay later in the season and reseeding with more pollinator-friendly mixes. This was seen to be contrary to the wider economic and 
practical considerations of farmers (Interviewee 5). Several interviewees extended such reservations by expressing scepticism about the ability of voluntary agri-environment schemes, which are lauded in the WPAP, to effect necessary changes to agricultural practice. This is particularly notable given that the BFA archives show a consistent historical failure of these voluntary schemes to support pollinators. For example, government strategy to control the negative impacts of pesticides has previously relied on farmers notifying beekeepers of plans to spray. This is not always practiced, nor is it always feasible for beekeepers to act on what are often last-minute plans (BFA Bulletins, Issues 108: October 1967; 181: August 1978).

Overall, many interviewees expressed concern that current pollinator strategy is, at best, merely 'tinkering on the edges' and a more systemic review is needed to overcome policy contradictions. In particular, initiatives to 'green' the Common Agricultural Policy were critiqued for their limited impact. Prevailing economic pressures to streamline farm businesses were also seen as running counter to efforts to diversify agricultural landscapes. Whilst this opinion was most forcefully expressed amongst newer beekeepers, who selfidentified with environmental motivations (cf. Moore and Kosut 2003, Nimmo 2015), most interviewees, regardless of their level of experience or particular approach followed, believed that the wider agricultural community and government are primarily driven to follow practices that are not in the best interest of pollinator health. This, they argued, is because the global food regime is dominated by corporate interests and food production has grown into an industry focused on exports and shareholder profits, rather than meeting basic nutritional needs in an environmentally sustainable way. Given these current power differentials, stacked in favour of agri-business, beekeepers see minimal scope for effective contest to these problematic norms. 
Set against this broader potentially defeating context, the push to include beekeepers' knowledges in a more participatory policy process is somewhat akin to the piecemeal adoption of traditional environmental knowledges (TEK) into dominant Western science noted by Doubleday (1998) and Nadasdy (2014). This, they argue, is doomed to fail as the benefits of TEK systems are compromised by external pressures that are contrary to their operation and values. Similarly, beekeepers in this study (both interviewees and in the archival record) felt that they were constrained in their efforts to support pollinator health by external factors beyond their control. For beekeepers to maximise the benefits of their distinctive knowledges would require a wider agricultural and environmental approach which is supportive of, and complementary to this knowledge. But there are continuing conflicts between what beekeepers know to be the most supportive conditions for bee health, and what is actually promoted due to economic, cultural and aesthetic values associated with the prevailing agricultural system (Potts et al. 2010b). This is leading to ineffective policy because whilst the WPAP and DEFRA's strategy do include laudable commitments, they are not tackling the need for wider change in agricultural and environmental systems which ultimately constrain any supportive actions.

\section{Conclusions}

There has been a dramatic increase in beekeeping in the UK in past ten years, and many people are approaching the activity with differing motivations and interests. Our findings demonstrate a number of tensions resulting from this increasing diversity within the sector, whilst also illustrating key unifying perspectives amongst both new and experienced beekeepers alike. Overall, our analysis presents a range of factors which could potentially impact on the future success of the WPAP and DEFRA's Pollinator Strategy. 
These include, firstly, perceived hierarchies and exclusions in the forms of knowledges included in the policy process; whereby beekeepers' observations remain secondary to formal scientific entomological and ecological study. It is also evident that some beekeepers' experience and perspective are granted more legitimacy than others, with those following more formal training and advice from government seen to have a stronger voice. This counters the very basis of a more participatory process in which diverse knowledges are granted equal weighting, acknowledging the differing strengths and weaknesses of all forms of knowledge. Secondly, we highlighted the social and political basis of policy-makers' evidence requirements and how the privileging of peer-reviewed science, as a prerequisite for evidence based policy, could lead to limitations in the effectiveness of policy actions. Finally and perhaps most importantly, as a persistent concern for all respondents, issues of policy clash and the continued predominance of productivist agriculture were discussed as potentially defeating pressures constraining any benefits gained through more progressive policy forums.

Drawing on these findings, we conclude with some key points to consider for further research into participatory pollinator policy forums, such as those in question here. Firstly, we emphasise questions about the control and directional flow of knowledge, given that beekeepers are providing their 'citizen science' to support monitoring projects and decision making that is ultimately beyond their control. This has critical impacts upon trust, which is vital to the success of any participatory programme. Here we emphasize that the aim of participatory policy and citizen science is not simply to deliver better information to policy makers, who then act upon this to make effective changes, rather the aim is to enable greater circulation and co-production of knowledges. Change through policy must also come from 
actions by publics beyond the forum of government. The WPAP and DEFRA strategy clearly acknowledge and advocate this, but if trust is eroded by a feeling of impotence and disenfranchisement then the process is undermined.

Secondly, is important to consider the impact that constant exposure to scrutiny and disregard can have on the diversity of knowledges beekeepers themselves respect and utilise. Here we can learn from research with indigenous communities on the sustainability of their TEK, in light of increasing contact and merging with western scientific knowledge systems (e.g. Davidson-Hunt 2006; Ogwuche 2012). For many beekeepers the fundamental centrality of traditional experiential learning - or constitutive expertise (Collins and Evans 2007) - is now being challenged, as the quantity of scientific research on bees has grown and become more accessible. This creates conflicts for new beekeepers in particular as they try to seek a 'right' answer, but struggle to rationalise the conflicting frames of science and traditional understandings. This also makes conflicts within the beekeeping community more common, and makes it harder to present a unified voice to external actors such as government and agribusiness.

Finally, and perhaps most worrying, is the potential for traditional approaches to become further marginalised. As the discussion here, and the work of others including Ruiz-Mallen and Corbera (2013), Suryanarayanan and Kleinman (2013) and Suryanarayanan (2015) show, diverse ways of knowing are critical to understanding - and ultimately solving environmental problems. This is a point that resonates beyond the specific concerns of beekeeping and pollinator conservation to wider rural land-use concerns. Traditional and constitutive expertise offer insights that science alone cannot provide. All knowledge forms are inherently limited in some ways, including those of science and government. We 
therefore need forums in which a range of expertise can come together, and whilst the rhetoric around pollinator policies advocates greater inclusion and a more genuinely participatory approach, the evidence presented here suggests there are substantive barriers to this happening.

As we have outlined, additional research is planned to gain further purchase on these issues. This is intended to engage with other actors involved in the WPAP and DEFRA strategies as these are implemented in order to advance a more thorough-going evaluation of the processes and politics involved. There-in a focus on knowledge politics and the sociology of expertise will be critical, alongside consideration of the political-economic and material factors involved.

\section{Acknowledgements}

The research for this paper was conducted with the support of an Access to Masters Scholarship, which is part-funded by the European Social Fund (ESF) through the European Union's Convergence programme administered by the Welsh Government. Thanks must also go to all of the research participants without whom this work would not have been possible. 


\section{References}

Barthel, S., Crumley, C., Svedin, U. 2013. Bio-cultural refugia-Safeguarding diversity of practices for food security and biodiversity. Global Environmental Change. 23: 1142-1152 Bates, T. 2015. Who is winning the PR battle over neonicotinoids? The Guardian March 19th online at: http://www.theguardian.com/sustainable-business/2015/mar/19/pr-battleneonicotinoids-decling-bee-colonies-food-security [last accessed 24/07/2015]

Bennett, J. 2010. Vibrant Matter. Duke University, Durham.

Berkes, F., Colding, J., Folke, C. 2000. Rediscovery of Traditional Ecological Knowledge as Adaptive Management. Ecological Applications. 10: 1251-1262

Blackstock, K,. Dinnie, L., Dilley, R., Marshall, K., Dunglinson, J., Trench, H., Harper, K., Finan, K., MacPherson, J., Johnston, E., Griffin, A., 2014 Participatory research to influence participatory governance: managing relationships with planners Area doi:10.1111/area.12129

Breeze, T., Roberts, S., Potts, S., 2012. The decline of England's Bees. University of Reading \& Friends of the Earth Available at http://www.foe.co.uk/resource/briefings/beesreport.pdf [last accessed 24/7/2015]

Buller, H., Morris, C. 2003. Farm Animal Welfare: A New Repertoire of Nature-Society Relations or Modernism Re-embedded? Sociologia Ruralis. 43: 216-237.

Collins, H., Evans, R., 2007. Rethinking Expertise. Chicago, IL: University of Chicago Press. Cooper, C. B., Dickinson, J., Phillips, T., Bonney, R., 2007. Citizen science as a tool for conservation in residential ecosystems. Ecology and Society. 12: 11.

Cook, B. R., Kesby, M., Fazey, I., Spray, C., 2013. The persistence of 'normal' catchment management despite the participatory turn: Exploring the power effects of competing frames of reference. Social Studies of Science. 43: 754 
Conrad, E., Cassar, L., Christie, M. Fazey, I., 2011. Hearing but not listening? A participatory assessment of public participation in planning. Environment and Planning C: Government and Policy 29: 761-782.

Cornwell, M., Campbell, L., 2012. Co-producing conservation and knowledge: Citizen-based sea turtle monitoring in North Carolina, USA. Social Studies of Science. 42: 101-120

Davidson-Hunt, I., 2006. Adaptive Learning Networks: Developing Resource Management Knowledge. Human Ecology. 34: 593-614

DEFRA, 2014. The National Pollinator Strategy for bees and other pollinators in England. Available at https://www.gov.uk/government/uploads/system/uploads/attachment_data/file/409431/pb142 21-national-pollinators-strategy.pdf [Last accessed 24/7/2015].

Dietmann, V. P., Werner, C., Crewe, R., 2014. Is there a need for conservation of honeybees in Africa? Apidologie. 40: 285-295.

Doubleday, N., 1998, Finding Common Ground: Natural Law and Collective Wisdom . In: Inglis, J., ed, 1998. Traditional Ecological Knowledge: Concepts and Cases Ottawa: International Development Research Centre. 41-53

Eden, S., Bear, C., 2011. Models of equilibrium, natural agency and environmental change: lay ecologies in UK recreational angling. Transactions of the Institute of British Geographers. 36: $393-407$

Eden, S., Donaldson, A., Walker, G., 2006. Green groups and grey areas: scientific boundary work, NGOs and the changing nature of environmental knowledge. Environment and Planning A. 38: 1061-1076

Ellis, R., Waterton, C., 2005. Caught between the cartographic and the ethnographic imagination. The whereabouts of amateurs, professionals and nature in knowing biodiversity. Environment and Planning D. 23: 673-693 
Enticott, G., 2008. The spaces of biosecurity: prescribing and negotiating solutions to bovine tuberculosis. Environment and Planning A 40: 1568-1582.

Eriscksen, P. 2008. Conceptualizing food systems for global environmental change research. Global Environmental Change. 18: 234-245

Farming Online 2015. NFU renews neonicotinoids appeal. 'Latest News'. 17th July. Online at http://www.farming.co.uk/news/article/11496

Fazey, I. Evely, A., Reed, M., Stringer, C. , Kruijsen, J., White, P., Newsham, A., Jin, L., Cortazzi, M., Phillipson, J., Blackstock, K., Entwistle, N., Sheate, W, Armstrong, F., Blackmore, C., Fazey, J., Ingram, J, Gregson, J., Lowe, P., Morton, S., Trevitt, C., 2013. Knowledge exchange: a review and research agenda for environmental management. Environmental Conservation, 40: 19-36.

Fish, R.D., Ioris, A.A.R., Watson, N.M., 2010. Integrating water and agricultural management: collaborative governance for a complex policy problem. Science of the Total Environment. 408: 5623-5630

Forsythe, T., 2011 Politicizing Environmental Explanations: What Can Political Ecology Learn from Sociology and Philosophy of Science? In: Goldman, M., Nadasdy, P., Turner, M., eds. Knowing Nature: Conversations at the intersection of political ecology and science studies. Chicago: University of Chicago Press Part 1: Introduction

Funtowicz, S., Ravetz, J., 1993. Science for the post-normal age. Futures 25: 739-755

Goldman, M., Turner, M., 2010. Introduction In Knowing Nature: Conversations at the intersection of political ecology and science studies. Chicago: University of Chicago Press.

Goldman, M., Nadasdy, P., Turner, M., eds. 2010. Knowing Nature: Conversations at the intersection of political ecology and science studies. Chicago: University of Chicago Press. 
Haklay, M. 2013. Citizen science and volunteered geographic information: Overview and typology of participation. In Sui, D., Elwood, S., Goodchild, M., eds. Crowdsourcing geographic knowledge, Chapter 7. Springer Netherlands.

Higgins, V., Potter, C., Dibden, J., Cocklin, C., 2014. Neoliberalising Rural Environments. Journal of Rural Studies. 36: 386-390.

Ingram, V., \& Njikeu, J., 2011. Sweet, sticky, and sustainable social business. Ecology and Society, 16:1.

Jasanoff, S., 2003. Breaking the waves in science studies: comment on H.M. Collins and Robert Evans, “The Third Wave of science studies"' Social Studies of Science. 33: 389-400

Lane, S., Odoni, N., Landstrom, C., Whatmore, S., Ward, N., Bradley, S., 2011. Doing flood risk science differently: An experiment in radical scientific method. Transactions of the Institute of British Geographers. 36: 15-36

Laurie, N., \& Bondi, L. (Eds.). 2006. Working the spaces of neoliberalism: activism, professionalisation and incorporation (Vol. 51). Wiley-Blackwell.

Le Conte, Y., de Vaublanc, G., Crauser, D., Jeanne, F., Rousselle, J-C., Bécard, J-M., 2007. Honey bee colonies that have survived varroa destructor. Apidologie. 38: 566-572.

LWEC [Living with Environmental Change], 2015, Protecting insect pollinators from pesticide risk (Policy \& Practice Note) LWEC. Available at http://www.lwec.org.uk/sites/default/files/attachments_biblio/LWEC\%20PP\%20Note\%2016 _WEB_0.pdf [Last accessed 21/ 4/ 2015]

Locke, B., Fries, I., 2011. Characteristics of honey bee colonies (Apis mellifera) in Sweden surviving Varroa destructor infestation - Springer. Apidologie. 42: 533-542.

Lorimer, J., 2008. Counting Corncrakes: The affective science of the UK corncrake census. Social Studies of Science. 38: 377-405

Miller, P. and Rose, N., 2008. Governing the Present. Polity Press. 
Moore, L. J., \& Kosut, M. 2013. Buzz: Urban Beekeeping and the power of the bee. New York University Press

Moore, L. J., \& Kosut, M. 2014. Among the colony: Ethnographic fieldwork, urban bees and intraspecies mindfulness. Ethnography. 15: 516-539

Nadasdy, P., 2003. Hunters and Bureaucrats: Power, Knowledge and Aboriginal-State Relations in the Southwest Yukon UBC Press, Vancouver BC

Nadasdy, P. 2014. The Politics of Tek: Power and the 'Integration' of Knowledge. Arctic Anthropology. 36:1-18.

Naug, D., 2009. Nutritional stress due to habitat loss may explain recent honeybee colony collapses. Biological Conservation. 142: 2369-2372.

Nimmo R. 2015. The Bio-Politics of Bees: Industrial Farming and Colony Collapse Disorder', Humanimalia: Journal of Human/Animal Interface Studies. 2: 1-20

Ogwuche, J., 2012. Integrating indigenous environmental knowledge into the environmental impact assessment process. Global Advanced Research Journal of Social Science. 1: 22-27. Orchid Apiaries 2013. Written Evidence Submitted to the UK Environmental Audit Committee on Insects and Insectcides. Available online at www.publications.parliament.uk/pa/cm201213/cmselect/cmenvaud/writev/668/m37.htm) [Last Accessed 24/07/2015]

Phillips, C., 2014. Following beekeeping: More-than-human practice in agrifood. Journal of Rural Studies. 36, 149-159

Phillipson, J., Lowe, P., Proctor, A., Ruto, E., 2012. Stakeholder engagement and knowledge exchange in environmental research. Journal of Environmental Management. 95: 56-65. Potts, S.G., Biesmeijer, J.C., Kremen, C., Neumann, P., Schweiger, O. and Kunin, W.E., 2010a. Global pollinator declines: trends, impacts and drivers. Trends in ecology \& evolution, 25(6): 345-353. 
Potts, S., Roberts, S., Dean, R., Marris, G., Brown, M., 2010b. Decline of managed honey bees and beekeepers in Europe. Journal of Apicultural Research. 49: 15-22.

Pretty, J., 2003. Agroecology in Developing Countries: The Promise of a Sustainable Harvest. Environment: Science and Policy for Sustainable Development. 45: 8-20

Proctor, A., Donaldson, A., Phillipson, J., \& Lowe, P., 2012. Field expertise in rural land management. Environment and Planning-Part A, 44: 1696.

Reed, M., 2008. Stakeholder participation for environmental management: A literature review. Biological Conservation 141: 2417-2431

Riesch, H., Potter, C., 2014. Citizen science as seen by scientists: Methodological, epistemological and ethical dimensions Public Understanding of Science 23: 107-1

Royer, M.-J., Herrmann, T, Sonnentag, O., \& Al, E., 2013. Linking Cree hunters' and scientific observations. Climatic Change. 119: 719-732.

Ruiz-Mallen, I., Corbera, E., 2013. Community-Based Conservation and Traditional Ecological Knowledge... Ecology and Society. 18:4

Suryanarayan, S., Kleinman, D., 2013. Be(e)coming experts: the controversy over insecticides in the honeybee colony collapse disorder. Social Studies of Science. 43: 215-240 Suryanarayan, S. 2015. Pesticides and pollinators: a context-sensitive policy approach. Current Opinion in Insect Science. 10:149-155

UK National Ecosystem Assessment (NEA), 2011. The UK National Ecosystem Assessment Technical Report. UNEP-WCMC, Cambridge.

UNEP, 2010. UN Environment Programme Emerging Issues: Global Honey Bee Colony Disorder and Other Threats to Insect Pollinators. Available Online at http://www.unep.org/dewa/Portals/67/pdf/Global_Bee_Colony_Disorder_and_Threats_insect _pollinators.pdf [Last accessed 24/7/2015]. 
Vandergeest, P., Peluso, N., 2011. Political violence and scientific forestry: Emergencies, Insurgencies, and Counterinsurgencies in Southeast Asia. In: Goldman, M., Nadasdy, P., Turner, M., eds. Knowing Nature: Conversations at the intersection of political ecology and science studies. Chicago: University of Chicago Press. Ch. 8

WG (Welsh Government), 2013. The Action Plan for Pollinators in Wales. Welsh Government. Available at http://gov.wales/docs/desh/publications/130723pollinator-actionplan-en.pdf [last accessed 24/7/2015].

Whatmore, S., 2009. Mapping knowledge controversies. Progress in Human Geography. 33: $587-598$

Woodyer, T., Geoghegan, H., 2012. (Re)enchanging geography? The nature of being critical and the character of critique in human geography. Progress in Human Geography. 37: 195214.

Wynne, B., 2003. Seasick on the third wave? Subverting the hegemony of propositionalism: Response to Collins and Evans (2002). Social Studies of Science 33(3): 401-417.

Wynne-Jones, S., North, P. and Routledge, P. 2015. Practising participatory geographies: potentials, problems and politics. Area, 47: 218-221.

Yarwood, R., Evans, N., 2000. Taking stock of farm animals and rurality. Animal Spaces, Beastly Places: 98-114.

Zimmerer K., 2011. Spatial-Geographic models of water scarcity and supply in irrigation and management: Bolivia, 1952-2009. In: Goldman, M., Nadasdy, P., Turner, M., eds. Knowing Nature: Conversations at the intersection of political ecology and science studies. Chicago: University of Chicago Press. Ch. 9 


\section{Appendix A}

List of Interviewees

\begin{tabular}{|c|c|c|c|}
\hline$\#$ & $\begin{array}{l}\text { Male / } \\
\text { Female }\end{array}$ & Respondent Details & Interview Date(s) \\
\hline 1 & $\mathrm{M}$ & $\begin{array}{l}\text { Professional bee farmer. Founder and CEO of Tropical Forest } \\
\text { Products Ltd. UK-wide and international level experience. }\end{array}$ & $\begin{array}{l}\text { Multiple interviews \& } \\
\text { informal } \\
\text { conversations through } \\
\text { work placement with } \\
\text { Tropical Forest } \\
\text { Products June-August } \\
2014 \text {. }\end{array}$ \\
\hline 2 & $\mathrm{~F}$ & $\begin{array}{l}\text { Bees for Development (BfD) African Project Officer. Has worked } \\
\text { with BfD for } 12 \text { years, and specialises in market analysis and } \\
\text { development. Has also written widely on extensive beekeeping. } \\
\text { UK-wide and international level experience. }\end{array}$ & 4 June 2014 \\
\hline 3 & $\mathrm{~F}$ & $\begin{array}{l}\text { Policy Advisor for BfD. Also lectures on sustainable beekeeping } \\
\text { and permaculture. UK-wide and international level experience. }\end{array}$ & 4 June 2014 \\
\hline 4 & $\mathrm{~F}$ & $\begin{array}{l}\text { Secretary of a local-level beekeepers association in Wales. Has } \\
\text { been keeping bees for } 30 \text { years. }\end{array}$ & 6 June 2014 \\
\hline 5 & $\mathrm{~F}$ & $\begin{array}{l}\text { Education Officer of a local-level beekeepers association in Wales } \\
\text {. Has been a beekeeper for } 13 \text { years. Interviewee 4's daughter, and } \\
\text { has been involved with beekeeping her entire life. Currently } \\
\text { works with FUW as a policy officer. Member of the Wales } \\
\text { Pollinator Taskforce. }\end{array}$ & 9 June, 15 July 2014 \\
\hline 6 & $\mathrm{M}$ & $\begin{array}{l}\text { Small scale hobbyist, who has been beekeeping for a few years; } \\
\text { previously based in England now in Wales. }\end{array}$ & 16 June 2014 \\
\hline 7 & $\mathrm{~F}$ & $\begin{array}{l}\text { Education officer for Welsh Beekeeping Association (WBKA). } \\
\text { Beekeeping for } 10 \text { years. Has an academic background in } \\
\text { agricultural science, and is currently in the process of taking } \\
\text { various exams run by BBKA. }\end{array}$ & 12 June 2014 \\
\hline 8 & $\mathrm{M}$ & $\begin{array}{l}\text { Author of The Barefoot Beekeeper. One of the UK's lead } \\
\text { proponents of top bar hives and sustainable beekeeping. }\end{array}$ & 18 June 2014 \\
\hline 9,10 & $\mathrm{~F}, \mathrm{~F}$ & $\begin{array}{l}\text { Two members of a local-level Bee Keepers Association in Wales, } \\
\text { interested in sustainable beekeeping and Warre Hives. They feel } \\
\text { they are not supported in their choices and interests by their } \\
\text { association. }\end{array}$ & 25 June 2014 \\
\hline 11,12 & $\mathrm{M}, \mathrm{F}$ & $\begin{array}{l}12 \text { is Chair of the WBKA; } 11 \text { is the Technical Advisor to the } \\
\text { WBKA, recently awarded an OBE for services to beekeeping. } \\
\text { They run beekeeping courses and are very involved in breeding }\end{array}$ & 26 June 2014 \\
\hline
\end{tabular}




\begin{tabular}{|l|l|l|l|}
\hline & & $\begin{array}{l}\text { local bee strains. } 12 \text { is a member of the Wales Pollinator } \\
\text { Taskforce and is very involved in promoting the importance of } \\
\text { locally adapted bees, and encouraging beekeepers not to import } \\
\text { bees. Both are research ecologists by training and profession. UK- } \\
\text { wide and international level experience. }\end{array}$ & \\
\hline 13 & M & $\begin{array}{l}\text { Author of The Bee-Friendly Beekeeper: A Sustainable Approach. } \\
\text { The UK's leading proponent of Warre hives. }\end{array}$ & 26 June 2014 \\
\hline 14 & M & $\begin{array}{l}\text { Retired publican / farmer and amateur beekeeper. Member of a } \\
\text { local-level Bee Keepers Association in Wales. Has 15 hives and } \\
\text { has been beekeeping for 5 years. }\end{array}$ & 11 July 2014 \\
\hline 15 & F & $\begin{array}{l}\text { Beekeeper for ten years. An academic researcher for DEFRA. UK- } \\
\text { wide experience. }\end{array}$ & 18 July 2014 \\
\hline 16 & M & $\begin{array}{l}\text { Academic researcher and second generation beekeeper. Member } \\
\text { of Wales Pollinator Task Force, and involved in DEFRA strategy. }\end{array}$ & $\begin{array}{l}\text { Multiple } \\
\text { June-August } 2014 .\end{array}$ \\
\hline
\end{tabular}




\section{Appendix B}

Details of conferences and meetings attended as a participant observer

9-11 August 2013: Natural Beekeepers Unconvention. Held at Green and Away, Worcester. Discussions on natural beekeeping and permaculture; locally adapted bees; observing bee behaviour to understand the health of the colony; the role of Bee Inspectors; different hive designs

10 April, 2014: More Than Honey film screening, organised by Aberystwyth Beekeepers Association (ABKA)

22 March 2014: Welsh Beekeepers Convention, Builth Wells: Talks given on managing swarms; good nutrition for bees; and the foundation of good comb

20 May 2014: Lecture by Wally and Jenny Shaw on Swarm Control / Making Increase (of hive numbers), organised by ABKA

5 July 2014: Bee Disease Workshop, presented by FERA and organised by ABKA

17 June 2014: Peter Guthrie lecture on bee feeding, organised by ABKA 